\title{
Abandonment of Conservation Agriculture by Smallholder Farmers in Zimbabwe
}

\author{
Tarisayi Pedzisa ${ }^{1}$, Lovemore Rugube ${ }^{1}$, Alex Winter-Nelson ${ }^{2}$, Kathy Baylis $^{2} \&$ Kizito Mazvimavi $^{3}$ \\ ${ }^{1}$ Department of Agricultural Economics, Extension and Rural Development, University of Pretoria, South Africa \\ ${ }^{2}$ Department of Agricultural and Consumer Economics, University of Illinois, United States \\ ${ }^{3}$ International Crop Research Institute for the Semi-arid tropics (ICRISAT), Zimbabwe \\ Correspondence: Tarisayi Pedzisa, Department of Agricultural Economics, Extension and Rural Development, \\ University of Pretoria, South Africa. E-mail: tpedzisa@yahoo.com
}

Received: October 28, 2014 Accepted: November 13, 2014 Online Published: January 22, 2015

doi:10.5539/jsd.v8n1p69 URL: http://dx.doi.org/10.5539/jsd.v8n1p69

\begin{abstract}
This paper examines the determinants of abandonment of conservation agriculture (CA) techniques among smallholder farmers in Zimbabwe. The analysis uses four rounds of a balanced panel from a survey aimed at monitoring CA adoption among farmers who participated in CA promotion projects. Findings indicate that a large share of farmers who had adopted CA during the period of active promotion eventually abandoned the practice in the absence of support from non-governmental organisations (NGOs). Households with more farming experience, bigger household sizes and a greater number of cultivated plots were less likely to stop using CA. In turn, wealthy households and farmers in the drier areas were more likely to stop using CA. The finding that persistent adoption is more prevalent among the poor, supports claims that CA is a pro-poor technology. Lastly, we find a strong, negative and robust relationship between continued NGO support and abandonment of CA. This finding suggests that improved support institutions are necessary to ensure that farmers continue to use CA as a productivity-boosting and sustainable farming method.
\end{abstract}

Keywords: conservation agriculture, technology adoption, abandonment, probit

\section{Introduction}

Following repeated bouts of severe food insecurity in Africa, several development agencies prescribed conservation agriculture (CA) as a promising response to declining yields that was suitable for drought prone communities (Hobbs, 2007; Shaxson, 2006). The objective of CA is to manage agro-ecosystems to improve productivity, while preserving the soil. CA rests on the three interlinked principles of minimal soil disturbance, permanent soil cover and crop rotation (FAO, 2013). Proponents of CA have emphasized its potential to provide resilience against drought and sustainably increase crop productivity (FAO, 2001). We study the continued use of manual CA, which involves farmers preparing planting basins using hand hoes. The emphasis on digging basins is central to the definition of CA among smallholders in Zimbabwe because it facilitates increased soil moisture, concentrates soil nutrients and minimizes the need for tillage thus reducing erosion from soil disturbance. Because soils in much of Zimbabwe are badly depleted, basin tillage is usually combined with use of chemical fertilizers to achieve productivity improvement. Though CA is generally purported to address the problem of intensive labor requirements in smallholder agriculture (Giller, Witter, Corbeels \& Titttonell, 2009), basin-tillage CA requires high labor input during land preparation and weeding. By allowing land preparation ahead of the onset of rains, CA does relieve a labor bottleneck at planting time.

Most studies of CA in Sub-Saharan Africa and elsewhere are limited to assessing the determinants of adoption versus non- adoption (Bekele \& Drake 2003; Doss, 2006; Tura et al., 2010). Abandonment is part of the adoption cycle that has historically been overlooked, despite the fact that technologies that are abandoned are as ineffective as technologies that are not adopted (Jones, 2005). In contrast to the vast number of empirical studies on technology adoption, little empirical evidence exists on the post-adoption behaviour of farmers (Oladele, 2005). The paucity of such studies may be attributed to data requirements because the analysis of decisions to retain or abandon previously adopted technologies requires information on multiple decisions over an extended period, rather than one decision at one point in time (Uematsu et al., 2010). Technology adoption decisions are 
inherently dynamic because farmers' decisions in one period critically depend on the decisions made in previous periods. For example, farmers do not simply decide whether to adopt an improved variety permanently, but instead make a series of decisions about whether to continue using the technology (Neil \& Lee, 2001). Farmer's adoption decisions need to be followed over a period, because ex-post information on technology adoption, such as its continued profitability, are important determinants of continued use of technology (Uematsu et al., 2010). Further, understanding who continues to use the technology may indicate who benefits most from its continued use. Examination of dis-adoption and continued use can yield insights into the constraints on the spread of a technology and guide efforts to make technologies more suitable or create conditions that support their use. This study examines dis-adoption in Zimbabwe and identifies institutional and technical factors that could lead to greater continued use of the technology.

\subsection{Conservation Agriculture in Zimbabwe}

In Zimbabwe CA programs have been championed and supported by the United Kingdom's Department for International Development and the European Commission Humanitarian Aid Office. While CA can take many different forms, in Zimbabwe digging basins distinguishes CA from conventional farming and is potentially consistent with minimum soil disturbance, permanent soil cover, crop rotation and improved productivity. Basins also allow for concentrating the benefits of supplemental fertilizers, which are required to restore the fertility of widely depleted soils. Through the Protracted Relief and Recovery Program, the donor community implemented CA programs in the context of short-term, ad hoc emergency relief and subsidized safety nets including free input deliveries and input subsidies (Anseeuw, Kapuya \& Saruchera, 2012).

In Zimbabwe, CA has been promoted as a solution to the production problems facing smallholder farming families (Mazvimavi \& Twomlow, 2009; Makwara, 2010). The focus of CA projects has been on the formulation of technological prescriptions for resource-poor farmers, though these prescriptions were largely developed and tested in researcher-managed trials, with only limited consideration of the problems and priorities of smallholder farmers (Stoop \& Kassam, 2005; Freidrich \& Kassam, 2009). The oft-asserted attractiveness and appropriateness of CA as a sustainable farming method for the poor is not reflected in patterns of uptake and continued use (Marenya \& Barrett, 2007; Mazvimavi \& Nyamangara, 2012). Critics of CA programs have noted that the projects have had only a limited success in addressing production constraints of smallholder farmers. Nhodo, Gukurume and Mafongoya (2011) argue that CA projects have fostered and entrenched a dependency syndrome through reliance on subsidized inputs.

Early predictions that CA would transform smallholder agriculture in Zimbabwe have been sharply contradicted by sluggish adoption, despite substantial initial support from non-governmental organisations (NGOs) (Gukurume, Nhodo \& Dube, 2010). Adoption of CA practices in Zimbabwe was encouraged through promotion and technical support provided by both NGOs and government (Mazvimavi et al., 2008). The critical inaccessibility of inputs immediately following Zimbabwe's Fast Track land reform of 2000 may have made farmers particularly responsive to CA promotion that provided fertilizer and seed on condition that recipients establish CA demonstration plots with basin tillage (Twomlow, Urolov, Jenrich \& Oldrieve, 2008). Linking CA with inputs for vulnerable households spurred initial adoption but continues to confound objective evaluation of CA technology. Even though promotion increased the number of farmers practicing CA, expansion in the CA area has been more modest (Marongwe et al., 2011). Moreover, most farmers have only adopted a subset of CA practices and more and more farmers are choosing to discontinue their use (Giller et al., 2009; Gowing \& Palmer, 2008).

\subsection{Study Objectives and Hypothesis}

1.3 This study seeks to understand factors affecting abandonment of basin CA in Zimbabwe. The role of NGO input support has often been assumed to be critical in the initial uptake of CA, particularly by poor and vulnerable households. Increasingly, CA is said to be a climate change adaptation strategy as well as a productivity enhancing technology. Given these assumptions and attributes of CA, this study was therefore informed by the following hypothesis

This study seeks to understand factors affecting abandonment of basin CA in Zimbabwe. The role of NGO input support has often been assumed to be critical in the initial uptake of CA, particularly by poor and vulnerable households. Increasingly, CA is said to be one of a climate change adaptation strategy as well as a productivityenhancing technology. Given these assumptions and attributes of CA, this study was therefore informed by the following hypothesis:

1) Households with greater access to NGO input and extension support are less likely to abandon CA. 
2) The poor and vulnerable are more likely to continue with CA.

3) Rates of abandonment of CA will vary by climatic zones within the country.

4) If the average yield of maize from all plots is low in the previous season, the household is likely to stop practicing CA.

5) The greater the farming experience, the greater the likelihood of continuation.

By testing these hypotheses, we intend to understand the patterns of abandonment and reveal constraints on adoption and continued use. Results are expected to indicate institutional and technical interventions to make CA more suitable for smallholder farmers.

\section{Method}

The study leverages a panel survey that began with PRP efforts to promote CA in 2003/4 and was intended to monitor the impacts of CA on adopters. Adoption of CA is measured through practice use of basin tillage as basins are a key technique which defines smallholder CA in Zimbabwe. A farmer is said to be a dis-adopter, if she or he stops using CA or specifically does not dig basins in any given round of the survey. Farmers participating in all rounds of the survey had adopted basin-tillage CA who had at least two years' experience of using CA prior to the 2006/7 round of the survey. These farmers represent early adopters. The data include farm households that were interviewed in 2007 and revisited in subsequent years until 2011

\subsection{Data}

The study uses a sub-sample of a five-year panel data set collected by the International Crops Research Institute for the Semi-arid Tropics. This paper uses data collected from 12 districts in four rounds of a panel survey from 2008 through to 2011 . The 12 districts were located throughout the country covering high rainfall, medium rainfall, semi-arid and very arid areas of the country. The balanced panel used in the analysis consists of 780 observations collected across four years from 195 households. Attrition in the study is around $10 \%$. Based on data from the 2007 survey round, farmers who dropped out of the survey are not different from those who continued with the panel. The level of attrition and the characteristics of the drop-outs are unlikely to introduce bias in the results.

Table 1 shows the number of farmers who stopped practicing CA through each round of the survey. The number of farmers dropping out of CA increased steadily from 2008 to 2011. The largest drop occurred from 2009 to 2010 when there were major policy shifts in the Zimbabwean economy, such as the introduction of multiple currencies that put a halt to hyperinflation, resulting in positive growth in GDP. A number of donor-supported input distribution projects ended at this point, which may have contributed to reduced adoption.

Table 1. Classification of farmers into persistent users and dis-adopters of CA

\begin{tabular}{ccccc}
\hline Season & $\begin{array}{c}\text { Observations } \\
\text { (n) }\end{array}$ & $\begin{array}{c}\text { Owns CA plot } \\
\text { (Continued user) }\end{array}$ & Dis-adoption rate (\%) & Re-adoption rate (\%) \\
\hline $2008 / 09$ & 195 & 186 & 4.6 & - \\
$2009 / 10$ & 195 & 171 & 12.3 & 3.1 \\
$2010 / 11$ & 195 & 144 & 26.1 & 3.6. \\
$2011 / 12$ & 195 & 138 & 29.3 & 11.8 \\
\hline
\end{tabular}

Source: Author Data Analysis, 2014

The decision to quit $\mathrm{CA}$ in any given season can be reversed in subsequent years if the conditions which deter the farmer from practicing CA are reversed. Farmers could reverse their dis-adoption because of a return of some favourable conditions such as receiving NGO input support in the later years. Adoption and dis-adoption are not associated with large fixed costs such that it is relatively easy to adopt and abandon basin tillage. However we only observe a few cases of re-adoption in the data.

The decision to quit $\mathrm{CA}$ in any given season can be reversed in subsequent years if the conditions that deter the farmer from practicing CA are reversed. Farmers could reverse their dis-adoption because of a return of some favourable conditions, such as receiving NGO input support, in later years. Adoption and dis-adoption are not associated with high fixed costs such that it is relatively easy to adopt and abandon basin tillage. However, we 
only observe a few cases of re-adoption in the data.

\subsection{Analytical Framework}

The econometric model and estimation strategy are informed by farmers' utility maximization. This framework assumes that abandonment is the optimal choice if utility from discontinuing with the technology is higher than the alternative. The household decides to discontinue the use of CA in a particular year if reducing the area planted with CA to zero increases utility (Carletto, Kirk, Winters \& Davis, 2007). Saha, Alan and Robert (1994) showed that adoption will be an optimal choice if the expected net marginal benefit of adoption exceeds zero. The abandonment of CA practices is treated as a binary variable equaling one when the area treated with CA practices (digging basins) is reduced to zero and zero otherwise (Neil \& Lee, 2001). Since dis-adoption is treated as a categorical variable, logit and probit methods can be used to study the farmers' decision. In this study, the logit model will be used to model abandonment. The probit model will be estimated as an alternative and for comparison purposes. (In practice estimations are made using STATA. The xtlogit and xtprobit commands are used as they are appropriate for panel data estimation.)

\subsection{Empirical Model Estimation}

The latent variable approach is used to model the decision of a farmer to quit or continue using CA. The latent variable, utility, is unobserved, but we can observe use of CA. If a farmer chooses to dis-adopt CA, we can conclude that the incremental utility CA offers is less than zero. Thus, dis-adoption of CA is an indicator variable for utility derived from CA versus the next best alternative.

Let the latent variable $\mathrm{C}^{*}$ it be defined as

$$
\mathrm{C}^{*}{ }_{\mathrm{it}}=\mathrm{X}_{\mathrm{it}} \beta+\mathrm{U}_{\mathrm{it}}+\alpha_{\mathrm{i}}+\mu_{\mathrm{t}}
$$

For farm $i$ in time $t$. The variable $\mathrm{X}_{\mathrm{it}}$ is a $1 \mathrm{x} \mathrm{K}$ vector (with first element equal to unity), $\beta$ is a $\mathrm{K} \times 1$ vector of parameters, $U_{i t}$ is normally distributed error term independent of $X_{i t}$, and $\alpha_{i}$ are time-invariant unobserved effects and $\mu_{\mathrm{t}}$ is a time varying error term (Wooldridge, 2002). An indicator variable $\mathrm{C}_{\mathrm{it}}$ represents farmer $i$ 's decision at time $t$ to stop practicing CA:

$$
\mathrm{C}_{\mathrm{it}}=1\left[\mathrm{C}^{*}{ }_{\mathrm{it}}>0\right]
$$

The distribution of $\mathrm{C}_{\mathrm{it}}$ given $\mathrm{X}_{\mathrm{it}}$ and the unobserved effect $\alpha_{\mathrm{i}}$ can be expressed as follows:

$$
\mathrm{P}\left(\mathrm{C}_{\mathrm{it}}=1 \mid X_{i t}, \alpha_{i}\right)=\varphi\left(X_{i t} \beta+\alpha_{i}\right), t=1 \ldots, T
$$

The parameters of interest will be estimated using the random effects logit (probit) model which requires an assumption that $\mathrm{V}_{\mathrm{i}}$ and $\mathrm{X}_{\mathrm{i}}$ are independent and that $\alpha_{\mathrm{i}}$ has a standard logistic distribution, i.e.:

$$
\alpha_{i} \mid X_{i} N\left(0, \pi^{2} / 3\right)
$$

The partial effects of the elements of $X_{\mathrm{t}}$ on the probability at the average value of $\alpha_{i}\left(\alpha_{i}=0\right)$ are estimated using a conditional maximum likelihood approach. Maximum likelihood estimates are obtained by taking the derivative of the log-likelihood with respect to the coefficients and correlation term. This approach is used to model abandonment decisions of an already adopted technology.

The variables that are hypothesized to influence abandonment are summarized in Table 2, as well as the expected signs in the abandonment equations. Most of the expected signs follow from the previous literature and the authors' familiarity with agriculture in Zimbabwe. 
Table 2. Definition of variable used in the model and their expected signs

\begin{tabular}{|c|c|c|}
\hline Variable & Definition & Expected sign \\
\hline Dis-adopt & Household without a CA plot $(0=$ continued use, $1=$ dis-adopt $)$ & $\begin{array}{l}\text { Dependent } \\
\text { variable }\end{array}$ \\
\hline NGO support & $\begin{array}{l}\text { Availability of NGO support (\% of households receiving NGO } \\
\text { support per ward) }\end{array}$ & - \\
\hline $\begin{array}{ll}\text { Total } & \text { livestock } \\
\text { holdings } & \end{array}$ & Total livestock by household in tropical livestock units (TLU) & + \\
\hline Total value of assets & Total value of household assets in US\$ & + \\
\hline Total cropped area & Log of total land under cropping for the season $\left(\mathrm{m}^{2}\right)$ & - \\
\hline Total no. of plots & Number of plots used by the household in any season & - \\
\hline Household size & Number of individuals in the household & - \\
\hline Female head & Head of household is male ( $1=y e s ; 0$ otherwise) & $-/+$ \\
\hline NR III & Household in Natural region III ( $1=y e s ; 0$ otherwise) & - \\
\hline NR IV & Household in Natural region IV ( $1=$ yes; 0 otherwise) & - \\
\hline NR V & Household in Natural region V (1=yes; 0 otherwise) & - \\
\hline 2009 & 2009 round of survey $1=$ yes; 0 otherwise) & + \\
\hline 2010 & 2010 round of survey $1=$ yes; 0 otherwise) & + \\
\hline 2011 & 2011 round of survey $1=y e s ; 0$ otherwise) & + \\
\hline CA experience & Years of using CA since first training (Years) & $-/+$ \\
\hline Farming experience & Years since household started farming (Years) & $-/+$ \\
\hline Education & Years of schooling of household head (Years) & $-/+$ \\
\hline Age & Age of household head & $-/+$ \\
\hline Lead farmer & Selected to assist other farmers with CA ( $1=$ yes; 0 otherwise) & - \\
\hline Extension visits & Frequency of extension contacts within a season & - \\
\hline Lag maize yield & Previous year's maize yield for the household $(\mathrm{kg} / \mathrm{ha})$ & - \\
\hline
\end{tabular}

Dis-adoption is measured as a dummy variable equal to one in any year a farmer has no field under basin-tillage CA and equal to zero if he/she has some land under CA. The NGO support variable attempts to capture access to CA education and relevant inputs. NGO support is measured as a proportion of households in a given ward that receive NGO support in any given year. Input support was mainly delivered in response to lack of farming inputs because of the deteriorating macroeconomic environment and as a response to drought prevailing in the country. Tropical livestock units (TLU) captures the value of all livestock (on four legs only) owned by a household. Each class of livestock is given a subjective value depending on its relative importance to the household with very high values allocated to cattle and the smallest allocated to goats and sheep. The total value of assets is measured by aggregating the value of all assets owned by the household based on 2011 prices at the village level. The total cropped area is log of the sum of all plots cultivated by a household measured in $\mathrm{m}^{2}$. The lag of maize yield is the average maize yield of the household whether from conventional or CA plots from the previous season. Ecological zones in Zimbabwe are classified as natural regions (NR) numbered I through to V. The most humid NR is I while NR IV and V are semi-arid to arid. The rest of the variables are measured as explained in Table 2 .

The model is specified based on the assumption that dis-adoption is likely to be influenced by many of the same factors that influence adoption. These factors can be classified as human capital (e.g. education, age), farm assets endowments and institutional and policy variables that are external to the household (Wendland \& Sills, 2008).

Institutional factors such as extension visits and access to NGO input support are expected to influence the adoption of CA practices. Extension provides farmers with the information on availability and properties of the new technology and technical skills for using it (Wozniak, 1997). Fertilizer donations are often conditioned on 
digging basins, hence farmers with more access to free fertilizer are likely to use basin tillage. However, the sustainability of such incentivized adoption is questionable, as observed by abandonment of CA once project support is ceased.

Lack of access to farm assets such as land or livestock, is also expected to limit the use of modern technologies. Nega and Sanders (2006) found that ownership of livestock promotes adoption and continued use of improved maize seed, since it generates income to finance the inputs associated with the technology and reduces the risks arising from crop failure. The technology under the current analysis does not require much land. Ndlovu, Mazvimavi, An, and Murendo (2013) and Mazvimavi et al., (2008) assert that CA is practiced on smaller plots compared to conventionally tilled plots thus land is not a binding constraint to CA adoption. Digging basins is meant to enable farmers with no access to draft power to plant early so that ownership of cattle may diminish the appeal of the practice of digging basins. Given the characteristics of the technology under investigation, it is expected that continued use will be prevalent amongst the poor who face constraints such as limited land and livestock.

Human capital endowments, usually captured by age, experience and education are the main factors treated in decisions of the household. Education increases the ability of farmers to obtain, process, and use information relevant to the technology, leading to greater use and sustainability of new technologies (Wozniak, 1994). Literate household heads are more likely to make informed decisions and apply a combination of practices effectively. Haggblade and Tembo (2003), note that the level of education and experience influences the ability of farmers to manage the technology. However, it is difficult to hypothesize a priori on the impact of experience on dis-adoption. More experience may allow learning by doing, which can make a new technology more profitable. On the other hand, experience might confirm that the technology is inappropriate.

We hypothesize that greater access to household labor supports continued use of CA while smaller households have a higher likelihood of dis-adopting because labor constraints may inhibit the use of CA. This hypothesis is supported by observations made by Grabowski (2011) that adoption of basin CA is constrained by increased labor requirements for land preparation and weeding. Sustained adoption is more likely in labor-abundant households. Female headed households typically have less access to labor and other productive resources, leading to low levels of adoption and high levels of dis-adoption (Croppenstedt, Demeke \& Meschi, 2003). However, programs promoting CA targeted resource-constrained smallholder farmers, including female-headed households. Because female-headed households were targets for training, they may be unlikely to dis-adopt, but labor shortages and other gender-specific constraints might encourage dis-adoption in these households.

Agro-ecology has a strong effect on yield and is a major factor influencing adoption and sustained use of CA practices. Pedzisa, (n.d) provided evidence that in the high potential areas (NR II), using CA has a positive and significant impact on yield, whereas using CA in the drier areas imposes a yield penalty. This implies that farmers in the dry areas of NR IV and V are more likely to dis- adopt CA compared to their counterparts in the wetter agro-ecological zones.

\section{Results and Discussion}

\subsection{Determinants of Continued User Category: Descriptive Statistics}

Table 3 gives the descriptive statistics for the variables used in the abandonment model and compares the characteristics of continued users and dis-adopters of CA. Approximately $72 \%$ of the sample farmers had access to input support from NGOs. The average age for the household head is 53 with an average farming experience of 27 years of which five years are years of CA experience. A quarter of the sample farmers are lead farmers The average household size is six and on average the household head has spent six years of formal education. An average household owns assets which have a value of US\$648 and livestock amounting to 2.89 TLU. Among the sample households the poorest do not own any assets or livestock. The distribution of farmers according to agro ecological zones (NRII, III, IV and V) is $23.1 \%, 24.4 \%, 32.2 \%$ and $20.6 \%$ respectively.

There are significant differences between the dis-adopters and other farmers in terms of access to NGO input support and based on the value of household assets (in US\$), size of cropped land (in $\mathrm{m}^{2}$ ), number of plots cultivated, household size, CA experience being a lead farmer and being located in NR II or NR V a high and low potential farming region respectively. However, there are no differences in terms of age of household head, education level, farming experience and livestock ownership (in TLU) between the two groups. The two groups of farmers received almost equal amounts of maize yield in the previous seasons. 
Table 3. Comparison of characteristics of continued users and abandoners

\begin{tabular}{lllll}
\hline Variable & Full sample $(\mathbf{n}=\mathbf{7 8 0})$ & Continued user $(\mathbf{n}=\mathbf{6 3 9})$ & Dis-adopter $(\mathbf{n}=\mathbf{1 4 1})$ & t-value $^{\mathbf{1}}$ \\
\hline NGO input support & 0.72 & 0.74 & 0.64 & $-5.02^{* * *}$ \\
Total livestock value & 2.89 & 2.81 & 3.26 & 1.42 \\
Total value of assets & 648.58 & 592.49 & 902.78 & $2.53^{* *}$ \\
Total cropped area & 9.48 & 9.30 & 9.52 & $-2.87^{* *}$ \\
Total no of plots & 5.70 & 5.98 & 4.42 & $6.20^{* * *}$ \\
Household size & 6.34 & 6.43 & 5.89 & $1.92^{*}$ \\
Female head & 0.50 & 0.49 & 0.55 & 1.29 \\
NR II & 0.23 & 0.25 & 0.14 & $-2.87^{* *}$ \\
NR III & 0.24 & 0.23 & 0.28 & 1.26 \\
NR IV & 0.32 & 0.33 & 0.30 & 0.51 \\
NR V & 0.21 & 0.20 & 0.28 & $2.14^{* *}$ \\
2009 & 0.25 & 0.27 & 0.17 & $-2.42^{* *}$ \\
2010 & 0.25 & 0.23 & 0.36 & $3.41^{* * *}$ \\
2011 & 0.25 & 0.22 & 0.40 & $4.73^{* * * *}$ \\
CA experience & 4.74 & 4.61 & 5.36 & $3.78^{* * *}$ \\
Farming experience & 26.66 & 26.91 & 25.54 & -1.04 \\
Education & 6.41 & 6.43 & 6.33 & 0.28 \\
Age & 53.12 & 52.77 & 54.70 & 1.46 \\
Lead farmer & 0.25 & 0.26 & 0.19 & $-1.81^{*}$ \\
Lmaizeyield & 1326.40 & 1415.03 & 1012.66 & $-1.91^{*}$ \\
\hline
\end{tabular}

Significance at the $10 \%, 5 \%$, and $1 \%$ levels are indicated by $* * *$ and $* * *$ respectively .Source: Author Data Analysis, 2014

Note. The t- test was based on dis-adoption versus continued use.

\subsection{Determinants of Abandonment - Econometric Estimation}

Table 4 presents the estimates of the abandonment model among CA beneficiaries. Three model specifications have been estimated for the random effects logistic model. Model 1 represents a generalized estimation of the logit model while Model 2 is the same as Model 1 except that it has various interaction terms added. Model 3 replicates Model 1 but it includes the lag of maize yield as an explanatory variable. The use of lagged measures of yield is meant to address the potential endogeneity of key farm level adoption determinants that arise when using cross-sectional data (Barham, Smith \& Moon, 2002). The dependent variable equals one if there is no area under CA and zero otherwise. Therefore, a positive coefficient indicates that the corresponding explanatory variable is positively associated with abandonment. The null hypothesis that all coefficients are simultaneously zero is rejected consistently at the $99 \%$ significance level.

Overall, access to NGO support, farming experience and household size significantly reduce the probability of abandoning CA. In turn, wealth indicators such as value of household assets owned by the household including number of plots cultivated by a household as well as the year dummies and drier agro-ecology significantly increase the probability of dis-adoption of CA. Probit model results presented in Table 5 are similar to those in Table 4 and are largely consistent with expected results in Table 2.

Access to NGO input support can help to overcome the challenges and constraints of adopting CA. Study results indicate that if a ward has a higher level of NGO support, households in that ward are likely to continue using CA. This variable is highly significant across the three model specifications. Female headed households who have greater access to NGO input support are even more likely to persist with CA as indicated by a $10 \%$ level of significance of the interaction of NGO support and female headed households. Female headed households therefore are particularly responsive to NGO support and are likely to persist with CA as a livelihood option and 
food security strategy when support is offered. The interaction of NGO support and livestock ownership is positive and significant at 5\% level implying that households with greater livestock assets are less influenced by NGO promotion than others. Overall, greater livestock assets correspond to greater likelihood of dis-adoption and lower a lower impact from NGOs. Given that livestock increases the availability of manure, the fertilizer provided by the NGOs may provide less of an incentive to adopt. Further, easier access to livestock implies that a household has less incentives to use basin -tillage for land preparation.

The total cropped area has no effect of the decision to abandon CA but the number of plots cultivated have implications on dis-adoption decisions. Households with more fragmented plots persist with CA presumably because they have more experimental options and greater capacity to spread risk over several fields than if they had fewer plots. Wealthier households, indicated by greater asset values are more likely to abandon CA than poor households. Wealthier households have a larger resource base and are likely to pursue other off- farm livelihood strategies and conventional tillage since CA is promoted as a technology for the poor. Female headed households are more likely to persist with CA than their male counterparts.

A larger household size implies greater access to labor, leading to a higher probability of continuing with CA compared to households with smaller families. Larger families are less labor constrained and are likely to persist with digging basins because they pool their labor resources. Experienced farmers tend to persist with CA suggesting that acquired experience and knowledge increases the return to using CA. Since CA is a knowledge intensive technology, learning by doing may come into play resulting in experienced farmers likely to continue using this technology.

Basin digging is enhanced by fertilizer application which is why the form of CA promoted in Zimbabwe is associated with small doses of nitrogen fertilizer and less emphasis on mulching (Nyamangara et al., 2014). Though CA is expected to overcome the constraint of rain water under dry-land farming, results indicate that farmers in the dry areas of NRV are more likely to quit compared to those in the wetter areas of NRII. Locational factors have an impact on adoption and dis-adoption decisions. In Zambia, farmers in the drier regions adopted CA because of its water conserving properties (Haggablade \&Tembo, 2003, Chomba, 2004). Our contradictory result may be due to differences in the cropping systems over agro ecological zones, with maize dominating in NR II and NR III, but small grains (sorghum and millet) becoming more common in NR IV and V.

The level of education and being a lead farmer do not affect abandonment decisions. Performance indicators such as previous maize yield do not seem to have an impact on the current decision to abandon CA as had been hypothesized. The test for robustness was effected by dropping re-adopters in all model specifications of abandonment. The household size variable, total asset and livestock variable and female headed household variable were not robust. Their significance diminished across all the model specifications. However, the results for the number of plots and access to NGO support were robust across all specifications.

Table 4 and 5 also displays marginal effects, which measure the percent change in the probability of adoption due to a one unit change in an explanatory variable. Marginal effects for the continuous variables in the Logit models are equal to:

$$
\mathrm{ME}=\beta \mathrm{P}(1-\mathrm{P})
$$

And in the Probit model is equal to:

$$
\mathrm{ME}=\phi(\beta \mathbf{X}) \beta^{-1}
$$

Where ME is the event probability at the chosen setting of $X$ and $\varphi$ is the probability density function, $X$ is the vector of exogenous variables and $\beta$ are the estimated parameters for X (Madalla, 1983). The marginal effects are measured at the mean value of the repressors. Marginal effects for the dummy variables are measured by taking the difference between the value of the prediction when the dummy equals 1 and when it equals 0 , holding all other variables at their respective means (STATA, 2003) 
Table 4. Logit estimates of abandonment of CA

\begin{tabular}{|c|c|c|c|c|c|c|}
\hline \multirow[b]{2}{*}{ Variable } & \multicolumn{2}{|l|}{ Model 1} & \multicolumn{2}{|l|}{ Model 2} & \multicolumn{2}{|l|}{ Model 3} \\
\hline & Coefficient & $\begin{array}{l}\text { Marginal } \\
\text { Effect }\end{array}$ & Coefficient & $\begin{array}{l}\text { Marginal } \\
\text { Effect }\end{array}$ & Coefficient & $\begin{array}{l}\text { Marginal } \\
\text { Effect }\end{array}$ \\
\hline NGO support & $\begin{array}{l}-2.364 * * * \\
(0.710)\end{array}$ & $-0.125 * *$ & $\begin{array}{l}-2.449 * * \\
(1.024)\end{array}$ & $-0.117 * *$ & $\begin{array}{l}-2.295^{* * *} \\
(0.615)\end{array}$ & $-0.238 * * *$ \\
\hline Total cropped area & $\begin{array}{l}0.057 \\
(0.218)\end{array}$ & 0.027 & $\begin{array}{l}0.049 \\
(0.223)\end{array}$ & 0.002 & $\begin{array}{l}-0.030 \\
(0.228)\end{array}$ & -0.003 \\
\hline Total no. of plots & $\begin{array}{l}-0.510 * * * \\
(0.087)\end{array}$ & $0.033 * * *$ & $\begin{array}{l}-0.512 * * * \\
(0.089)\end{array}$ & $0.024 * * *$ & $\begin{array}{l}-0.330^{* * *} \\
(0.079)\end{array}$ & $-0.034 * * *$ \\
\hline Total value of assets & $\begin{array}{l}0.0003 * \\
(0.0002)\end{array}$ & $0.0002^{*}$ & $\begin{array}{l}0.0003 * \\
(0.0002)\end{array}$ & $0.00002 *$ & $\begin{array}{l}0.0004 * \\
(0.0002)\end{array}$ & $0.00004 *$ \\
\hline Total livestock value & $\begin{array}{l}0.057 \\
(0.050)\end{array}$ & 0.003 & $\begin{array}{l}-0.224 \\
(0.140)\end{array}$ & 0.011 & $\begin{array}{l}0.031 \\
(0.059)\end{array}$ & 0.003 \\
\hline Education & $\begin{array}{l}0.014 \\
(0.057)\end{array}$ & 0.001 & $\begin{array}{l}0.003 \\
(0.060)\end{array}$ & 0.0001 & $\begin{array}{l}-0.040 \\
(0.057)\end{array}$ & -0.004 \\
\hline Age & $\begin{array}{l}0.033^{*} \\
(0.019)\end{array}$ & $0.002 *$ & $\begin{array}{l}0.033^{*} \\
(0.020)\end{array}$ & $0.002 *$ & $\begin{array}{l}0.037^{*} \\
(0.020)\end{array}$ & $0.004 *$ \\
\hline Farming experience & $\begin{array}{l}-0.036^{* *} \\
(0.017)\end{array}$ & $-0.002 * *$ & $\begin{array}{l}-0.039 * * \\
(0.018)\end{array}$ & $0.002 * *$ & $\begin{array}{l}-0.044 * * \\
(0.018)\end{array}$ & -0.005 \\
\hline Household size & $\begin{array}{l}-0.098^{*} \\
(0.057)\end{array}$ & $0.005^{*}$ & $\begin{array}{l}-0.114 * * \\
(0.059)\end{array}$ & $0.005^{*}$ & $\begin{array}{l}-0.089 \\
(0.060)\end{array}$ & -0.010 \\
\hline *Female head & $\begin{array}{l}-0.620^{*} \\
(0.379)\end{array}$ & $0.033^{*}$ & $\begin{array}{l}0.924 \\
(0.912)\end{array}$ & 0.045 & $\begin{array}{l}0.088 \\
(0.367)\end{array}$ & 0.010 \\
\hline *NR III & $\begin{array}{l}1.179 * * \\
(0.557)\end{array}$ & $0.084 *$ & $\begin{array}{l}1.053^{*} \\
(0.584)\end{array}$ & 0.066 & $\begin{array}{l}0.769 \\
(0.540)\end{array}$ & 0.093 \\
\hline *NR IV & $\begin{array}{l}1.380 * * * \\
(0.544)\end{array}$ & $0.094 * *$ & $\begin{array}{l}1.389 * * \\
(0.571)\end{array}$ & $0.087 *$ & $\begin{array}{l}0.991 * \\
(0.531)\end{array}$ & $0.117 *$ \\
\hline *NR V & $\begin{array}{l}1.948 * * * \\
(0.570)\end{array}$ & $0.178^{* *}$ & $\begin{array}{l}2.016 * * * \\
(0.598)\end{array}$ & $0.173 * *$ & $\begin{array}{l}1.389 * * \\
(0.566)\end{array}$ & $0.198 * *$ \\
\hline *2009 & $\begin{array}{l}1.466^{* * *} \\
(0.508)\end{array}$ & $0.111 * *$ & $\begin{array}{l}1.627 * * * \\
(0.531)\end{array}$ & $0.118^{* *}$ & & \\
\hline *2010 & $\begin{array}{l}3.880 * * * \\
(0.561)\end{array}$ & $0.499 * * *$ & $\begin{array}{l}4.108 * * * \\
(0.594)\end{array}$ & $0.516^{* * *}$ & & \\
\hline *2011 & $\begin{array}{l}2.982 * * * \\
(0.548)\end{array}$ & $0.329 * * *$ & $\begin{array}{l}3.142 * * * \\
(0.576)\end{array}$ & $0.334 * * *$ & & \\
\hline Lead farmer & $\begin{array}{l}-0.143 \\
(0.407)\end{array}$ & -0.007 & $\begin{array}{l}0.061 \\
(0.424)\end{array}$ & 0.003 & $\begin{array}{l}-0.353 \\
(0.413)\end{array}$ & -0.034 \\
\hline Lmaize_yield & & & & & $\begin{array}{l}-0.0003 \\
(0.0001)\end{array}$ & -0.00001 \\
\hline NGO*female & & & $\begin{array}{l}-2.279^{*} \\
(1.190)\end{array}$ & $-0.109 *$ & & \\
\hline NGO*livestock & & & $\begin{array}{l}0.421 * * \\
(0.189)\end{array}$ & $0.020 * *$ & & \\
\hline Constant & $\begin{array}{l}-2.283 \\
(2.298)\end{array}$ & & $\begin{array}{l}-2.112 \\
(2.382)\end{array}$ & & $\begin{array}{l}0.811 \\
(2.338)\end{array}$ & \\
\hline Observations & 780 & & 780 & & 564 & \\
\hline Log likelihood & -265.202 & & -261.414 & & -240.997 & \\
\hline $\begin{array}{l}\text { Predicted likelihood } \\
\text { disadoption }(\%)\end{array}$ & 5.6 & & 5.0 & & 11.7 & \\
\hline AIC & 568.895 & & 564.827 & & 515.994 & \\
\hline $\mathrm{BIC}$ & 657.421 & & 662.672 & & 589.659 & \\
\hline
\end{tabular}

Standard errors in parentheses. Significance at the $10 \%, 5 \%$, and $1 \%$ levels are indicated by *,** and *** respectively. $\left({ }^{*}\right) \mathrm{dy} / \mathrm{dx}$ is for discrete change of dummy variable from 0 to 1

Source: Author Data analysis, 2014 
NGO support has the largest marginal effect in all model specifications for CA abandonment, followed by the year and natural region dummies. The number of plots cultivated by the farmer also has a strong marginal effect. Increasing the percent of households receiving NGO support in the ward by $1 \%$ in any given year reduces the probability of dis-adopting CA by $12 \%$. Among female headed households this effect is almost twice as great. Meanwhile, an additional plot to the household fields reduces the same probability by about $8 \%$.

An additional year of farming experience reduces the probability of abandoning CA by $1.9 \%$ whereas an additional year on the age of household head increases the same probability by $1.7 \%$. The marginal effect of total value of assets is $0.03 \%$. The year dummies and agro-ecology are positively related to abandonment of CA. As one would suspect, households were more likely to have abandoned CA in 2010 when NGO activity declined compared to 2008 . The probability of quitting CA increased by $50 \%$ in 2010 , then drops to $32 \%$ in 2011 and finally $10 \%$ in 2009 . Households in the drier areas of NR V and NR IV are respectively $19 \%$ and $11 \%$ more likely to quit using CA compared to NR II.

The logit model has lower AIC and BIC values compared to the probit model indicating a better fit.

Table 5. Probit estimates of abandonment of CA

\begin{tabular}{|c|c|c|c|c|c|c|}
\hline \multirow[b]{2}{*}{ Variable } & \multicolumn{2}{|l|}{ Model 1} & \multicolumn{2}{|l|}{ Model 2} & \multicolumn{2}{|l|}{ Model 3} \\
\hline & Coefficient & $\begin{array}{l}\text { Marginal } \\
\text { Effect }\end{array}$ & Coefficient & $\begin{array}{l}\text { Marginal } \\
\text { Effect }\end{array}$ & Coefficient & $\begin{array}{l}\text { Marginal } \\
\text { Effect }\end{array}$ \\
\hline NGO support & $\begin{array}{l}-1.291 * * * \\
(0.393)\end{array}$ & $-0.148 * *$ & $\begin{array}{l}-1.352 * * \\
(0.567)\end{array}$ & $-0.142 * *$ & $\begin{array}{l}-1.276^{* * *} \\
(0.347)\end{array}$ & $-0.261 * * *$ \\
\hline Total cropped area & $\begin{array}{l}0.045 \\
(0.121)\end{array}$ & 0.005 & $\begin{array}{l}0.0410 \\
(.123)\end{array}$ & 0.004 & $\begin{array}{l}-0.025 \\
(0.129)\end{array}$ & -0.005 \\
\hline Total no. of plots & $\begin{array}{l}-0.288^{* * *} \\
(0.048)\end{array}$ & $0.033 * * *$ & $\begin{array}{l}-0.287 * * * \\
(0.048)\end{array}$ & $0.030 * * *$ & $\begin{array}{l}-0.190 * * * \\
(0.044)\end{array}$ & $-0.039 * * *$ \\
\hline Total value of assets & $\begin{array}{l}0.0002 * \\
(0.0001)\end{array}$ & $0.0002 *$ & $\begin{array}{l}0.0002 * \\
(0.0001)\end{array}$ & $0.00002 *$ & $\begin{array}{l}0.0002 * \\
(0.0001)\end{array}$ & $0.00004 *$ \\
\hline Total livestock value & $\begin{array}{l}0.032 \\
(0.028)\end{array}$ & 0.004 & $\begin{array}{l}-0.124 \\
(0.079)\end{array}$ & 0.013 & $\begin{array}{l}0.018 \\
(0.034)\end{array}$ & 0.004 \\
\hline Education & $\begin{array}{l}0.010 \\
(0.032)\end{array}$ & 0.001 & $\begin{array}{l}0.004 \\
(0.032)\end{array}$ & 0.0004 & $\begin{array}{l}-0.023 \\
(0.033)\end{array}$ & -0.005 \\
\hline Age & $\begin{array}{l}0.018 * \\
(0.011)\end{array}$ & $0.002 *$ & $\begin{array}{l}0.018 * \\
(0.011)\end{array}$ & 0.002 & $\begin{array}{l}0.022^{*} \\
(0.011)\end{array}$ & $0.004 *$ \\
\hline Farming experience & $\begin{array}{l}-0.020 * * \\
(0.010)\end{array}$ & $-0.002 * *$ & $\begin{array}{l}-0.022 * * \\
(0.010)\end{array}$ & $0.002 * *$ & $\begin{array}{l}-0.025 * * \\
(0.010)\end{array}$ & -0.005 \\
\hline Household size & $\begin{array}{l}-0.058^{*} \\
(0.032)\end{array}$ & $0.007 *$ & $\begin{array}{l}-0.066^{* *} \\
(0.033)\end{array}$ & $0.007 *$ & $\begin{array}{l}-0.049 \\
(0.034)\end{array}$ & -0.010 \\
\hline *Female head & $\begin{array}{l}-0.360^{*} \\
(0.210)\end{array}$ & $0.042 *$ & $\begin{array}{l}0.474 \\
(0.506)\end{array}$ & 0.050 & $\begin{array}{l}0.049 \\
(0.208)\end{array}$ & 0.010 \\
\hline *NR III & $\begin{array}{l}0.661 * * \\
(0.316)\end{array}$ & $0.100^{*}$ & $\begin{array}{l}0.590^{*} \\
(0.318)\end{array}$ & 0.080 & $\begin{array}{l}0.432 \\
(0.304)\end{array}$ & 0.100 \\
\hline *NR IV & $\begin{array}{l}0.770 * * * \\
(0.315)\end{array}$ & $0.111^{* *}$ & $\begin{array}{l}0.771 * * \\
(0.312)\end{array}$ & $0.103 *$ & $\begin{array}{l}0.545^{*} \\
(0.298)\end{array}$ & $0.123 *$ \\
\hline$* N R$ V & $\begin{array}{l}1.078 * * * \\
(0.323)\end{array}$ & $0.198 * *$ & $\begin{array}{l}1.108 * * * \\
(0.327)\end{array}$ & $0.193 * *$ & $\begin{array}{l}0.785 * * \\
(0.319)\end{array}$ & $0.205^{* *}$ \\
\hline *2009 & $\begin{array}{l}0.788 * * * \\
(0.276)\end{array}$ & $0.124 * *$ & $\begin{array}{l}0.876^{* * *} \\
(0.286)\end{array}$ & $0.132 * *$ & & \\
\hline *2010 & $\begin{array}{l}2.128 * * * \\
(0.314)\end{array}$ & $0.490 * * *$ & $\begin{array}{l}2.247 * * * \\
(0.314)\end{array}$ & $0.506^{* * *}$ & & \\
\hline *2011 & $\begin{array}{l}1.638 * * * \\
(0.322)\end{array}$ & $0.340 * * *$ & $\begin{array}{l}1.720 * * * \\
(0.306)\end{array}$ & $0.346 * * *$ & & \\
\hline Lead farmer & $\begin{array}{l}-0.028 \\
(0.223)\end{array}$ & -0.003 & $\begin{array}{l}0.010 \\
(0.231)\end{array}$ & 0.001 & $\begin{array}{l}-0.194 \\
(0.233)\end{array}$ & -0.038 \\
\hline Lmaize_yield & & & & & $\begin{array}{l}-0.00002 \\
(0.00004)\end{array}$ & -0.00001 \\
\hline
\end{tabular}




\begin{tabular}{|c|c|c|c|c|}
\hline NGO $*$ female & & $\begin{array}{l}-1.222 * \\
(0.656)\end{array}$ &.$-0.128 *$ & \\
\hline NGO*livestock & & $\begin{array}{l}0.234 * * \\
(0.106)\end{array}$ & $0.025 * *$ & \\
\hline Constant & $\begin{array}{l}-1.354 \\
(1.298)\end{array}$ & $\begin{array}{l}-1.262 \\
(1.318)\end{array}$ & & $\begin{array}{l}0.511 \\
(1.325)\end{array}$ \\
\hline Observations & 780 & 780 & & 564 \\
\hline Log likelihood & -265.447 & -261.760 & & -240.912 \\
\hline $\begin{array}{l}\text { Predicted likelihood for } \\
\text { dis-adoption }(\%)\end{array}$ & 5.7 & 5.1 & & 12.4 \\
\hline AIC & 568.895 & 565.510 & & 515.824 \\
\hline $\mathrm{BIC}$ & 657.421 & 663.365 & & 589.490 \\
\hline
\end{tabular}

Standard errors in parentheses. Significance at the $10 \%, 5 \%$, and $1 \%$ levels are indicated by $*, * *$ and $* * *$ respectively. $\left({ }^{*}\right) \mathrm{dy} / \mathrm{dx}$ is for discrete change of dummy variable from 0 to 1

Source: Author Data analysis, 2014

\subsection{Conclusion}

This paper contributes to the literature on agricultural technology adoption generally, and specifically on CA adoption in the context of Zimbabwe. In particular, this study represents one step toward understanding the post-adoption behaviour of farm households. Technology adoption requires close monitoring to determine whether households continue to use the practice and to use it appropriately. Equally important, understanding why farmers dis-adopt technology can inform efforts to develop more appropriate technical innovations or support services. The paper provides insights into the key factors associated with dis-adoption of CA. The results reveal that human capital, asset endowment, institutional variables and agro ecology all affect dis-adoption decisions. Abandonment is evident despite the fact that this technology has been supported through the provision of technical knowledge and inputs and has been tested by farmers. Results point to a need for continued institutional support to enable CA practices and room for technical adaptations to CA to make is more feasible for smallholders.

The observed relationship between the loss of NGO support and abandonment of CA suggests that understanding the importance of subsidized input provision is essential to design future programs for CA promotion. Continued incentives and support services may be necessary to ensure that farmers continue to use CA. As practiced in Zimbabwe, CA is most effective if it includes the use of chemical fertilizers. If these fertilizers are unavailable, $\mathrm{CA}$ is unlikely to be practiced. In the past fertilizer distribution was closely linked to NGO programs. While it is clear that loss of those programs has contributed to the abandonment of $\mathrm{CA}$, it is not clear whether commercial fertilizer has been available in the absence of NGO programs. As a result, it is difficult to discern whether private sector distribution of fertilizer could support CA practices in the absence of NGO services. Research to understand the role of the private sector in distributing fertilizer and thereby facilitating CA might yield insights into alternative mechanisms to encourage the practice sustainably.

In addition to institutions to ensure access to inputs needed to make CA profitable, results indicate that institutions to help farmers learn to use CA could be important. CA is a complicated and labor-intensive technology. Farmers who have practiced CA over a protracted period persist with the practice. The use of CA seems to be enhanced through learning by doing since it takes time to appreciate and understand how the technology works. The use of demonstration plots and effective technical backstopping support may be helpful when designing CA promotional programs and continued advisory services may support continued CA practice. The performance of the technology and its profitability are key determinants in the acceptability of any technology by farmers.

These findings suggest that poor, vulnerable households are more likely to persist with CA than wealthier households. This result confirms that CA is accessible to the poor, who are the target group for this technology. Institutional innovations could support expanded use by the poor, but some households appear to be less suited to the technology due to technical rather than institutional factors. A strong tendency towards dis-adoption in semi-arid and arid regions such as NR V raises the question about the suitability of CA in those regions. However, it is unclear whether the weak persistence of CA in those marginal regions is due to ecological or institutional factors. That the areas where dis-adoption is most common are also areas better suited to millet and sorghum than maize, suggests that there may be room to better adapt CA to settings where maize is a secondary 
rather than primary crop. The observation that increased household size reduces the probability of dis-adoption suggests that labor constraints may prohibit some households from practicing CA. Technical innovations to reduce labor demands, as well as effective extension to facilitate learning, could contribute to more persistent use of CA.

The analysis clearly indicates that better screening of agro-ecological and socio-economic constraints and incentives for adoption of CA are needed in order to achieve effective and durable adoption of CA in Zimbabwe. The CA policy should be aimed at supporting poor and vulnerable farmers with inputs and extension advice so that they sustainably adopt this pro-poor technology. However, defining the appropriate system for ensuring delivery of inputs and services remains a challenge.

\section{Acknowledgments}

The authors gratefully acknowledge the International Crops Research Institute for the Semi-Arid Tropics (ICRISAT) - Bulawayo office for supporting this study by providing access to CA panel data set. Funding for collection of data was provided by the Protracted Relief Program (PRP) which was funded by a consortium of donor and managed by GRM International.

\section{References}

Anseeuw, W., Kapuya, T., \& Saruchera, D. (2012). Zimbabwe's agricultural reconstruction: Present state, ongoing projects and prospects for reinvestment. Development Planning Division Working Paper Series No. 32. Development Bank of Southern Africa.

Barham, B. L., Smith, D. J., \& Moon, S. (2002). The Dynamics of Agricultural Biotechnology Adoption: Lessons from rBST use in Wisconsin, 1994-2001. Selected Paper for Presentation at the American Agricultural Economics Association Annual Meetings, Long Beach, California, July 28-31.

Bekele, W., \& Drake, L. (2003). Soil and water conservation decision behavior of subsistence farmers in the Eastern Highlands of Ethiopia: a case study of the Hunde -Lafto area. Ecological Economics, 46(3), 437-451. http://dx.doi.org/10.1016/S0921-8009(03)00166-6

Carletto, C., Kirk, A.,Winters, P., \& Davis, B. (2007). Non-traditional Exports, Traditional Constraints: The Adoption and Diffusion of Cash Crops among Smallholders in Guatemala. (ESA Working Paper No. 07-03). Rome: Food and Agriculture Organization.

Chomba, G. (2004) Factors affecting smallholder farmers' adoption of soil and water conservation practices in Zambia. (Unpublished MSc thesis). Department of Agricultural Economics, Michigan State University

Croppenstedt, A., Demeke, M. \& Meschi, M. M., (2003). Technology Adoption in the Presence of Constraints: The Case of Fertilizer Demand in Ethiopia. Review of Development Economics, 7, 58-70. http://dx.doi.org/10.1111/1467-9361.00175

Doss, C. R. (2006). Analysing Technology Adoption using micro-studies: Limitations, challenges and

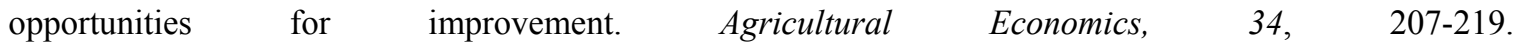
http://dx.doi.org/10.1111/j.1574-0864.2006.00119.x

FAO. (2001). The economics of soil productivity in Africa. Rome: Soils Bullet

FAO. (2008). Investing in Sustainable Crop Intensification. The case of Soil Health. Report of the International technical Workshop, FAO, Rome, July. Integrated Crop Management. Vol 6, Rome. FAO.

FAO. (2013). What is conservation agriculture? Retrieved October 24, 2013, from http://www.fao.org/ag/ca/1a.html

Friedrich, T., \& Kassam, A. H. (2009). Adoption of Conservation Agriculture Technologies: Constraints and Opportunities. Invited paper at the IV World Congress on Conservation Agriculture. 4-7 February 2009, New Delhi, India.

Giller, K. E., Witter, E., Corbeels, M., \& Tittonell, P. (2009). Conservation agriculture and smallholder farming in Africa: The heretics' view. Field Crops Research, 114, 23-34. http://dx.doi.org/10.1016/j.fcr.2009.06.017

Gowing, J. W., \& Palmer, M. (2008). Sustainable Agriculture Development in Sub-Sahara Africa: The Case of a Paradigm Shift in Land Husbandry. Soil Use and Management, 24, 92-99. http://dx.doi.org/10.1111/j.1475-2743.2007.00137.x

Grabowski, P. (2011). Constraints to adoption of conservation agriculture in the Angonia highlands of Mozambique: perspectives from smallholder hand-hoe farmers. (Unpublished MSc thesis). Michigan State 
University, Michigan.

Gukurume, S., Nhodo, L., \& Dube, C. (2010). Conservation farming and the food security- insecurity matrix in Zimbabwe: A case of ward 21 Chivi Rural. Journal of Sustainable Development in Africa, 12(7), 39-52.

Haggblade, S., \& Tembo, G. (2003). Conservation farming in Zambia. EPTD Discussion Paper 8. Environment and Production Technology Division, International Food Policy Research Institute.

Hobbs, P. R. (2007). Conservation agriculture, what is it and why is it important for future sustainable food production? Journal of Agriculture Science, 145, 127-137. http://dx.doi.org/10.1017/S0021859607006892

Jones, K. M. (2005). Technology Adoption in West Africa: adoption and dis-adoption of soybeans on the Togo-Benin border. (Unpublished MSc thesis), Graduate Faculty of North Carolina State University

Maddala, G. (1983). Limited dependent and qualitative variables in econometrics. New York: Cambridge University Press. http://dx.doi.org/10.1017/CBO9780511810176

Makwara, E. C. (2010). Sustainable and Profitable farming through conservation agriculture in Zimbabwe: prospect, opportunities and constraints. Journal of sustainable development in Africa, 12(8), 180-190.

Marenya, P. P., \& Barrett, C. B. (2007). Household-level determinants of adoption of improved natural resources management practices among smallholder farmers in western Kenya. Food Policy, 32(4), 515-536. http://dx.doi.org/10.1016/j.foodpol.2006.10.002

Marongwe, L. S., Kwazira, K., Jenrich, M., Thierfelder, C., Kassam, A., \& Friedrich, T. (2011). An African success: the case of conservation agriculture in Zimbabwe. International Journal of Agricultural Sustainability, 9(1), 153-161. http://dx.doi.org/10.3763/ijas.2010.0556

Mazvimavi, K., \& Nyamangara, J. (2012). Dynamics in conservation farming adoption intensity, 2007-2010. Presented at the Presentation to the CA Task Force, 21 January 2011, Harare, Zimbabwe: pp. 1-16.

Mazvimavi, K., \& Twomlow, S. (2009). Socioeconomic and institutional factors influencing adoption of conservation farming by vulnerable households in Zimbabwe. Agricultural Systems, 101(1-2), 20-29. http://dx.doi.org/10.1016/j.agsy.2009.02.002

Mazvimavi, K., Twomlow, S., Belder, P., \& Hove, L. (2008). An Assessment of the Sustainable Adoption of Conservation Farming in Zimbabwe. Global Theme on Agro ecosystems. Report number 39, Bulawayo Zimbabwe: ICRISAT, 60pp.

Ndlovu, P. V., Mazvimavi, K., An, H., \& Murendo, C. (2013). Productivity and Efficiency Analysis of Maize under Conservation Agriculture in Zimbabwe. Agricultural Systems, 124, 21-31. http://dx.doi.org/10.1016/j.agsy.2013.10.004

Nega, G. W., \& Sanders, J. H. (2006). Farm-level adoption of sorghum technologies in Tigray, Ethiopia. Agricultural Systems, 91, 122-134. http://dx.doi.org/10.1016/j.agsy.2006.02.002

Neill, P. S., \& Lee, D. R. (2001). Explaining the adoption and dis-adoption of sustainable agriculture: The case of cover crops in Northern Honduras. Economic Dev. Cult. Change, 49(4), 793-820. http://dx.doi.org/10.1086/452525

Nhodo, L., Gukurume, S., \& Mafongoya, O. (2011). Contestations and conflicting life worlds in Conservation farming practices in Zimbabwe: The experiences of peasant smallholder farmer in Chivi South in Masvingo. Russian Journal of Agriculture, Socio-Economic Sciences, 4(16), 19-30.

Nyamangara, J., Chikowo R., Ruinahodzi, L., \& Mazvimavi, K. (2014). Conservation agriculture in Southern Africa. In R. A. Jat, L. Kanwar, A. Sahrawat, \& A. H. Kassam (Eds.), Conservation agriculture: global prospects and challenges (pp 339-351). CABI. http://dx.doi.org/10.1079/9781780642598.0339

Oladele, O. I. (2005). A Tobit analysis of propensity to discontinue adoption of agricultural technology among farmers in south western Nigeria. Journal of Central European Agriculture, 6(3), 249-254.

Pedzisa, T. (n.d). Determinants of Intensification and Abandonment of Basin Conservation Agriculture among Smallholder Farmers in Zimbabwe. (Unpublished PhD Thesis forthcoming). University of Pretoria, South Africa.

Saha, L., Alan, L. H., \& Robert, S. (1994). Adoption of emerging technologies under output uncertainty. American Journal of Agricultural Economics, 76, 836-846. http://dx.doi.org/10.2307/1243745

Shaxson, T. F. (2006). Re-thinking the conservation of carbon, water and soil: a different perspective. Agronomie, $26,1-9$. 
Stoop, W. A., \& Kassam, A. H. (2005). The SRI controversy; a response. Field Crops Res., 91, 357-360. http://dx.doi.org/10.1016/j.fcr.2004.07.023

Tura, M, Aredo, D., Tsegaye, W., Rovere, R. L., Tesfahun, G., Mwangi, W., \& Mwabu, G. (2010). Adoption and continued use of improved maize seeds: Case study of Central Ethiopia. African Journal of Agricultural Research, 5(17), 2350-2358.

Twomlow, S., Urolov, J. C., Jenrich, M., \& Oldrieve, B. (2008). Lessons from the field-Zimbabwe's Conservation Agriculture Task Force. Journal of SAT Agricultural Research, 6, 11.

Uematsu, H., Mishra, A. K., Roberts, R. K., Lambert, D. M., \& English, B. C. (2011). Motivation for Technology Adoption and Its Impact on Abandonment: A Case Study of U.S. Cotton Farmers. Southern Agricultural Economics Association Annual Meeting. Corpus Christi, Texas.

Uphoff, N., \& Kassam, A. H. (2009). System of Rice Intensification (SRI). Agriculture for Developing Countries. Science and Technology Options Assessment (STOA) Project. Karlsruhe, Germany: European Technology Assessment Group.

Wendland, K. J., \& Sills, E. O. (2008).Dissemination of food crops with nutritional benefits: Adoption and dis-adoption of soybeans in Togo and Benin. Natural Resources Forum, 32(1), 39-52. http://dx.doi.org/10.1111/j.1477-8947.2008.00169.x

Wozniak, G. D. (1984). The Adoption of Interrelated Innovations: A Human Capital Approach. Review of Economics and Statistics, 66(1), 70-79. http://dx.doi.org/10.2307/1924697

\section{Copyrights}

Copyright for this article is retained by the author(s), with first publication rights granted to the journal.

This is an open-access article distributed under the terms and conditions of the Creative Commons Attribution license (http://creativecommons.org/licenses/by/3.0/). 